\title{
Bioética e Direitos Humanos: Tratamento Teórico da InTERface
}

BIOETHICS AND HUMAN RIGHTS: THEORIST

APPROACH OF THIS INTERCONNECTION

Aline Albuquerque S. de Oliveira ${ }^{(*)}$

\section{RESUMO}

Esta pesquisa tem como escopo identificar de que modo bioeticistas explicitam a relação entre Bioética e direitos humanos, expondo pontos de contato e distanciamento entre os dois campos. Também, objetiva-se apresentar sinteticamente um panorama das implicações que envolvem a conjugação do referencial dos direitos humanos com a Bioética quando se trata de dilemas morais em saúde pública. Para tanto, verificou-se como a interface entre Bioética e direitos humanos vem sendo estabelecida por bioeticistas que trazem a linguagem dos direitos humanos para sua reflexão teórica. Esse levantamento partiu da análise de trabalhos teóricos de bioeticistas, publicados nos últimos cinco anos, que de alguma forma tocam na problemática - a interface entre Bioética e direitos humanos -, focandose nos de origem latino-americana, estadunidense e europeia. $O$ exame da literatura bioética atual demonstrou que, em termos teóricos, não se constata a presença de um discurso uníssono sobre a conexão entre a Bioética e os direitos humanos, o que enuncia o processo de construção no qual ainda se encontra a Bioética, assim como a pluralidade de fundamentações éticas que permeia sua produção teórica. Quando se trata de dilemas morais em saúde pública, buscou-se demonstrar que a análise bioética, uma vez escolhido esse parâmetro ético avaliativo para o exame de políticas e práticas sanitárias, pode lançar mão de princípios de direitos humanos, o que se entendeu como recomendável, mormente em razão de tais princípios fundamentarem eticamente a atuação do Estado, o principal responsável pela proteção da saúde da população.

(*) Advogada da União, coordenadora de Legislação e Normas do Ministério da Saúde, mestre em Direito e doutoranda em Ciências da Saúde/Bioética. E-mail: <aline.oliveira @saude.gov.br>. Recebido em 31.08.09. Aprovado em 01.09.09. 


\section{Palavras-chave}

Bioética; Direitos Humanos; Saúde Pública.

\section{ABSTRACT}

This research intends to identify the way bioethicists explain the relation between Bioethics and human rights, pointing out the areas where they meet and where they distance themselves. It also attempted to briefly present a panorama of the implications that involve the convergence of human rights and Bioethics in terms of moral dilemmas in public health. The methodological steps encompass: analysis of how the interface between Bioethics and human rights has been established by bioethicists, who bring the human rights language into their researchers' theoretical observation; and examination of some bioethicists' theoretical work published in the last five years and that somehow deals with the interface between Bioethics and human rights, focusing on researchers from Latin America, United States and Europe. Investigation of the current bioethics literature showed that, in theoretical terms, there is no evidence of a uniform discourse on the connection between Bioethics and human rights, which announces the process of construction that Bioethics is going through, as well as the plurality of ethical fundaments that permeate Bioethics theoretical production. When dealing with moral dilemmas in public health, we tried to show that Bioethics analysis can make use of human rights principles, once this ethical assessment parameter is chosen for the investigation of sanitary policies and practices. The reason behind this choice is that such principles are the ethical basis for the State acting - and the State is the main responsible for the protection of the health of the population.

\section{Keywords}

Bioethics; Human Rights; Public Health.

\section{INTRODUÇÃO}

O presente artigo visa identificar de que modo teóricos dos estudos sobre Bioética explicitam a relação entre Bioética e Direitos Humanos, expondo pontos de contato e distanciamento entre os dois campos. Esse recorte tem como justificativa a concepção de que a relevância de se conjugar o referencial dos Direitos Humanos com a Bioética precisa ser observável quando se trata de 
dilemas morais em Saúde Pública. Além disso, a investigação da interface entre Bioética e Direitos Humanos contribui para a solidificação de ambos os saberes, bem como para estudos cujo objeto atravessa a Bioética e os Direitos Humanos. Ademais, quando se trata de lançar mão das normas e princípios de Direitos Humanos no âmbito da avaliação ética em Saúde Pública, busca-se, por um lado, reforçar a proteção da pessoa humana e sua dignidade inerente e, por outro lado, reafirmar a responsabilidade jurídica e moral dos Estados de prover as condições de vida digna.

Para tanto, foram examinados trabalhos acadêmicos de autores que se debruçam sobre o estudo da conexão entre Bioética e Direitos Humanos sob o viés bioético, ou seja, não foram consideradas obras de estudiosos do Direito, relativas à penetração da Bioética no campo jurídico. Assim, com base nesse material, se identificaram distintos modos propostos por bioeticistas teóricos para expor relações entre Bioética e os Direitos Humanos, considerando a primeira como campo específico do saber que se desdobra em três perspectivas: Bioética Teórica, Bioética Institucional e Bioética Normativa - divisão que será considerada neste trabalho. Desse modo, a despeito da relevância de se investigar o modo como se dá a conexão entre Bioética e Direitos Humanos à luz das instituições bioéticas e de suas normativas, optouse por fazer um recorte e focou-se na identificação e análise das formas como se constroem teoricamente as conexões entre Bioética e Direitos Humanos, estabelecidas na bibliografia bioética.

Ainda, objetivou-se levantar os pontos de contato e distanciamento outrora identificados na literatura bioética e em atos normativos internacionais, tais como a Declaração Universal sobre Bioética e Direitos Humanos, com o objetivo de concorrer para o aprofundamento de pesquisas em torno das interconexões entre Bioética e Direitos Humanos, pois o fortalecimento de ambos, enquanto corpo teórico e prescritivo, é essencial para a cimentação de uma cultura humanista.

Os passos metodológicos envolvem, na etapa inicial, a verificação de que modo a interface entre Bioética e Direitos Humanos vem sendo estabelecida por bioeticistas que trazem a linguagem dos Direitos Humanos para sua reflexão teórica. Foram analisados trabalhos teóricos de bioeticistas, publicados nos últimos cinco anos, que de alguma forma tocam na problemática - a interface entre Bioética e Direitos Humanos - , focando-se nos de origem latino-americana, estadunidense e europeia. A partir desse exame constatou-se que, embora lançar mão do discurso dos direitos humanos seja recorrente, poucos, de fato, se ocupam da análise dos desdobramentos que permeiam a junção dos dois campos ou buscam criar um espaço dentro da Bioética que empregue os direitos humanos como referencial teórico. Quanto ao recorte proposto ao se realizar o levantamento, cabe sublinhar que não foram considerados os artigos de bioeticistas cuja temática centrouse na crítica à inserção dos Direitos Humanos na Declaração Universal sobre 
Bioética e Direitos Humanos ou cingiu-se ao exame da interface à luz da Declaração. Sendo assim, decidiu-se por estabelecer quatro categorizações para demonstrar que a interface entre Bioética e Direitos Humanos é observável sob diferentes aspectos, assim como para explicitar que não há como se determinar, no atual estágio de desenvolvimento teórico da Bioética, uma percepção única da sua ligação com os Direitos Humanos.

No que toca à proposição desta pesquisa, de identificar pontos de contato e afastamento essenciais entre Bioética e Direitos Humanos, seguiu-se, metodologicamente, a mesma demarcação do levantamento inicial.

A seguir, será exposta uma explicação sobre as três perspectivas Bioéticas, no próximo item far-se-á uma explanação sobre o conceito de Direitos Humanos, adotado neste artigo, e, em seguida, tratar-se-á das categorizações das abordagens teóricas, encontradas na literatura bioética atual. Por fim, serão identificados pontos de contato e distanciamento entre a Bioética e os Direitos Humanos, conferindo ênfase na relação entre esses e a Saúde Pública.

\section{BIOÉTICA TEÓRICA, INSTITUCIONAL E NORMATIVA}

Inicialmente, é importante ressaltar que não há um conceito unívoco de Bioética, nem um consenso sobre o que pode ser entendido como o fenômeno bioético. Essa afirmação encontra respaldo na ausência de consenso sobre o conceito de Bioética quando da elaboração da Declaração Universal sobre Bioética e Direitos Humanos, assim como na não inserção do termo "bioética" no título da Convenção Europeia sobre os Direitos Humanos e da Biomedicina. Inclusive a delegação alemã destacou o sentido pejorativo da palavra em seu país e em outros de língua alemã ${ }^{(1)}$. Não obstante a dificuldade de se estabelecer um conceito delimitado para Bioética, para os fins desta pesquisa parte-se de determinadas características básicas da Bioética com o objetivo de delimitar sua semântica no âmbito deste trabalho. Então, formatando-a conceitualmente, a Bioética é caracterizada como uma ética aplicada de natureza interdisciplinar, cuja apresentação se dá sob a forma de discursos e práticas; assim como se distingue por se configurar como análise ética direcionada para a tomada de decisões ${ }^{(2)}$. Explicando melhor, ao tratar da natureza da Bioética, Durand( ${ }^{(3)}$ destaca que mesmo aqueles que evitam rotulá-la como uma ética, de alguma forma, a situam nesse plano ao fazerem referência a "assuntos éticos", "reflexão de ordem

(1) INSTITUTO DE BIOÉTICA. Direitos do homem e biomedicina. Lisboa: Universidade Católica, 2003.

(2) PARIZEAU, M. H. Bioética. In: CANTO-SPERBER, M. (Org.). Dicionário de ética e filosofia moral. Caxias do Sul: Unisinos, 2003. p. 166-169.

(3) DURAND, G. Introdução geral à bioética. São Paulo: Loyola, 2003. 
ética" ou a "escolhas éticas". O problema em torno da natureza da Bioética está na possibilidade de se conjugar sua essência interdisciplinar com a sua substância ética. Para responder essa indagação Durand ${ }^{(4)}$ diferencia método, natureza e objetivo da Bioética. Sua natureza e seu objetivo são essencialmente éticos, porquanto objetiva a reflexão ética e a construção de um saber teóricoprático sobre questões ligadas à vida e à saúde, no entanto, seu método é interdisciplinar.

De uma forma geral, os autores estadunidenses classificam a Bioética como uma ética aplicada, assim como na França, o Comitê Consultivo Nacional de Ética (CCNE) trata de seus temas conferindo-Ihes uma carga de preocupação ética(5). Na América Latina também se percebe a predominância do entendimento de que a Bioética é uma ética aplicada ${ }^{(6)}$.

Quanto à sua caracterização como teórica e prática, a Bioética toma a forma de discursos e práticas. Discursos que se materializam em monografias, revistas especializadas, etc., e práticas, tais como comitês de ética em pesquisa, comitês hospitalares ${ }^{(7)}$. Parizeau ${ }^{(8)}$ afirma: "a bioética define-se, portanto, por essa forte interação simbólica e de linguagem." Para esse autor, a bioética discursiva ou teórica e a prática possuem em comum a análise ética de casos e problemas, que, por sua vez, constitui-se de duas partes principais: a primeira, de natureza reflexiva, volta-se para o exame das questões éticas em jogo, dos métodos de reflexão, dos valores e princípios em causa, e para a análise dos argumentos aduzidos; a segunda é de cunho eminentemente normativo, pois tem como escopo a tomada de decisão.

Partindo-se do entendimento da Bioética como um saber teórico-prático de natureza interdisciplinar, cujo objetivo é a reflexão ética a questões ligadas à vida e à saúde, Callahan ${ }^{(9)}$ fala de variedades de Bioética, quais sejam: Bioética Teórica; Ética Clínica; Bioética Normativa; e Bioética Cultural. Nesta pesquisa são adotadas as seguintes variações do campo bioético: Bioética Teórica; Bioética Normativa; e Bioética Institucional. Comparando a classificação perfilhada no presente trabalho e a formulada por Callahan, verifica-se que se incluiu a Bioética Institucional e se excluiu a Ética Clínica e a Bioética Cultural. Explicando o recorte, a Ética Clínica refere-se a questões éticas quotidianas imbricadas na relação médico-paciente, que se encontram, segundo nossa acepção, englobadas pela Bioética Teórica quando produz reflexões teóricas sobre tal relação ou pela Institucional, por meio da análise da atividade dos Comitês de Ética Hospitalar. Quanto à Bioética Cultural,
(4) DURAND, G. op. cit.
(5) Id. Ibid.
(6) KOTTOW, M. Introducción a la bioética. Santiago do Chile: Mediterráneo, 1995.
(7) PARIZEAU, M. H. op. cit. p. 166-169.
(8) Id. Ibid., p. 167.
(9) CALLAHAN, D. Bioethics. In: ENCYCLOPEDIA of bioethics. 3. ed. New York: Macmillan, 2004. p. 278-287. 
que busca relacionar a Bioética com os contextos culturais, sociais e ideológicos nos quais ela se expressa, entendemos que se enquadra na percepção teórica do fenômeno bioético quando se dá a partir de disciplinas como a Antropologia e a Sociologia. Inspirando-se na divisão da Bioética proposta por Callahan com os ajustes propostos acima, nesta pesquisa a Bioética será tratada sob a consideração de suas três perspectivas: Teórica, Normativa e Institucional.

A Bioética Teórica é definida como o conjunto de teorias e princípios cuja natureza é de ética aplicada e tem como objeto dilemas morais relacionados à saúde e à vida. Ela não se conforma num conjunto de princípios e teorias universais e unívocos, há variadas correntes e escolas bioéticas que mantêm sustentações teóricas e práticas muito distintas sob as perspectivas ideológica, filosófica, religiosa e política(10).

A Bioética Normativa é compreendida como o conjunto de normas bioéticas, não obstante o reconhecimento de que também detêm natureza jurídica. Para que determinado instrumento normativo seja enquadrado como bioético, dois pressupostos devem estar presentes, um de ordem formal e outro material. No que diz respeito à forma como o instrumento foi produzido, ele deve ter sido fruto de uma produção coletiva dialogada e democrática, não importando, para tanto, se posteriormente houve o acolhimento da proposição normativa por um poder estatal ou organismo internacional. A caracterização exigida aqui se refere aos debates, às discussões em que vários posicionamentos puderam ter sido colocados e levados em conta com igual consideração. Quanto a esse ponto, lança-se mão do pensamento de Habermas ${ }^{(11)}$, pois essas "discussões (e negociações) constituem o local em que vontade política racional pode se formar, a suposição de resultados legítimos, que deve fundamentar o procedimento democrático." O requisito que se apóia na ética do discurso, busca avaliar a legitimidade da normativa e não se houve o respeito a parâmetros de legalidade. $O$ outro aspecto da construção normativa em Bioética refere-se ao conteúdo material das normativas, ou seja, aquilo que foi incorporado ao seu texto. Para que uma normativa seja caracterizada como Bioética seu conteúdo deve ser Bioético, as normas devem conter princípios bioéticos derivados do arranjo democrático e pluralista produtor da normativa. Assim, uma norma é bioética quando, além de ser fruto de um processo diferenciado e qualificado de produção, também traz em seu corpo comandos que, em verdade, são princípios bioéticos. A natureza dessas normas, além de Bioética, é jurídica, isso significa que contêm princípios também jurídicos, visto que estão dispostos em instrumentos com validade jurídica. Dessa delimitação, se infere que há uma interpenetração entre os campos bioético e jurídico, ou seja, em

(10) BUENO, G. Que es la bioética. Oviedo: Pentalfa, 2001.

(11) HABERMAS, J. A constelação pós-nacional. São Paulo: Littera Mundi, 2001. p. 148. 
algumas situações uma mesma norma pode ser percebida à luz do Direito ou da Bioética, em função de sua dupla natureza - que pode ser observada, por exemplo, na Declaração Universal sobre o Genoma Humano e Direitos Humanos, na Declaração Internacional sobre Dados Genéticos, na Declaração Universal sobre Bioética e Direitos Humanos, na Convenção sobre Direitos Humanos e Biomedicina do Comitê de Ministros do Conselho da Europa. Por outro lado, também se extrai da noção de Bioética Normativa, empregada nesta pesquisa, que essa não se confunde com o denominado "Biodireito", pois esse abrange todas as normas jurídicas que possuem interface com temáticas bioéticas, tais como eutanásia, aborto, pesquisa envolvendo seres humanos, independentemente da legitimidade presente no processo de produção normativa. Portanto, é o conceito de "Biodireito" muito mais amplo do que o adotado nesta pesquisa.

A Bioética Institucional envolve dois tipos de instituição, as que possuem funções cuja natureza é essencialmente bioética, como os comitês: de revisão ética de pesquisas envolvendo seres humanos; os que prestam aconselhamento ético em decisões clínicas; e os que possuem funções mais amplas relacionadas à avaliação do desenvolvimento científico e tecnológico, formulação de diretrizes bioéticas e promoção do debate e da educação em bioética. $E$ as instituições que apresentam papel variado, mas que se manifestam acerca de temáticas bioéticas. Essas instituições são relevantes para a Bioética, não em razão da função que exercem, pois não possuem natureza essencialmente bioética - de revisão ética - mas em virtude de se destinarem ao aprofundamento de reflexões em bioética ou examinar os desdobramentos éticos de determinadas ações praticadas pela instituição. Como exemplo, pode-se citar o Comitê Internacional de Bioética (CIB), e o Comitê Intergovernamental de Bioética (CIGB), ambos da UNESCO.

Dessa forma, considerando que a Bioética é definida de variadas formas, como, por exemplo, "disciplina que estuda implicações éticas", "filosofia de investigação", "setor ou parte da ética", "ética aplicada", "ética particularmente centrada" e "ciência sistemática do homem ético"(12), foi preciso estabelecer uma noção de Bioética da qual se parte para estabelecer sua correlação com o campo dos Direitos Humanos. Sendo assim, entende-se, neste trabalho, que a Bioética é uma espécie de ética aplicada, caracterizada como interdisciplinar, cujo paradigma é composto por teorias dedutivas, marcadas por princípios. Resumindo o exposto, temos, então, o entendimento de que a bioética, enquanto objeto de conhecimento, pode ser percebida de três formas diferentes: Bioética teórica, a ênfase é dada nas teorias e argumentações que estruturam sua reflexão; Bioética Normativa, cujo objeto de estudo é as normas bioéticas, entendidas como as que decorrem de debate bioético - plural e democrático - e possuem conteúdo principiológico; e, por fim, a Bioética Institucional, composta pela análise das práticas e

(12) DURAND, G., op. cit. 
manifestações dos comitês de natureza ética, bem como por organismos e órgãos que detêm competência para tratar de questões bioéticas. Uma vez delineada a noção de Bioética Teórica, foco desta pesquisa, passa-se à descrição do conceito de Direitos Humanos ora acolhido.

\section{DIREITOS HUMANOS: DIREITOS MORAIS POSITIVADOS}

$\mathrm{Na}$ perspectiva estadunidense, a distinção entre direitos morais e direitos legais é corrente. Os sistemas morais e jurídicos não apresentam o mesmo tipo de exigências, assim, uma exigência moral pode ser ou não juridicamente formalizada e vice-versa. Logo, pode-se ter o direito legal de fazer algo patentemente imoral ou se ter um direito moral sem a correspondente garantia legal. Os direitos legais derivam dos atos normativos formais do Estado, tais como a Constituição, leis e normas do Poder Executivo; já os direitos morais existem independentemente, e formam a base para crítica ou justificativa dos direitos legais ${ }^{(13)}$. No entanto, neste trabalho adota-se a concepção de que os Direitos Humanos são direitos morais, mas não no sentido conferido pelo sistema jurídico estadunidense. O entendimento aqui defendido de que os Direitos Humanos são direitos morais baseia-se na acepção construída por Fernández, como a seguir será explicado.

A compreensão do conteúdo dos Direitos Humanos implica o estudo, mesmo que não aprofundado, do problema da busca de sua justificação racional, isto é, "o conceito de Direitos Humanos não pode ser separado do tema do fundamento" (14). Não obstante reconheça-se que para alguns teóricos não se faça mais necessário a busca de um fundamento ou justificativa, ou seja, como apontado por Bobbio(15), o problema prioritário em relação aos Direitos Humanos não é tanto o de justificá-los, mas o de protegê-los. Entretanto, entende-se, neste trabalho, que a proteção dos Direitos Humanos por meio de mecanismos legais e com algum conteúdo coercitivo é correlata a buscas de justificações, não absolutas, como ressalta o próprio Bobbio(16). Nesse sentido, o comentário de Barreto ${ }^{(17)}$ contribui para o aprofundamento da percepção da relevância de se assentar um conceito racionalmente justificado para os Direitos Humanos: "A necessidade de uma fundamentação não se esgota somente na necessidade de dar-se uma resposta ao argumento autoritário, mas encontra-se, também, nas próprias sociedades democráticas contemporâneas".

(13) BEAUCHAMP, T.L.B. Introduction to ethics. In: BEAUCHAMP, T.L.; WALTERS, L. (Orgs.) Contemporary issues in bioethics. New York: Thomson, 2003. p. 1-37.

(14) FERNANDÉZ, E. Teoria de la justicia y los derechos humanos. Madrid: Editorial Debate, 1984. p. 82.

(15) BOBBIO, N. A era dos direitos. São Paulo: Campus, 1993.

(16) Id. Ibid.

(17) BARRETO, V. Bioética, biodireito e direitos humanos. In: TORRES, R. Lobo (Org.) Teoria dos direitos fundamentais, Rio de Janeiro: Renovar, 1999. p. 377-417. 
Freeman $^{(18)}$ destaca que é preciso buscar justificativas para o conceito de Direitos Humanos, porquanto seja a base de uma teoria de legitimidade do Estado. No entanto, assinala que não é possível um consenso em torno da sua justificativa teórica, visto que existem inúmeras escolas filosóficas. Assim, considerando que há variadas perspectivas teóricas que alicerçam a fundamentação dos Direitos Humanos, neste trabalho optou-se pela explanação de uma vertente, a fundamentação ética proposta por Fernandéz ${ }^{(19)}$, que parte das seguintes inter-relações: Direitos Humanos e a dignidade humana e Direitos Humanos como direitos morais. Essa escolha deu-se em virtude da fundamentação desenvolvida por Fernandéz ser a que, ao nosso entender, melhor explora o conteúdo ético dos Direitos Humanos, aspecto essencial para conectá-los com a Bioética.

A fundamentação ética não rechaça a jusnaturalista, pois reconhece que a sua influência nos documentos de Direitos Humanos, principalmente do século XVIII, é inquestionável, assim como acolhe a historicista, ao demonstrar que fatores históricos, como os valores do liberalismo e a irrupção do socialismo ao fim do século XIX, são condicionantes do surgimento dos Direitos Humanos ${ }^{(20)}$. Assim, tal fundamentação dos Direitos Humanos estabelece que a origem e o fundamento dos Direitos Humanos não são jurídicos, constituem-se em fenômenos pré-jurídicos. O fato de um direito humano ter sido incorporado a uma norma jurídica de direito positivo não significa que foi esse fenômeno de incorporação legislativa que o criou, na verdade, houve o seu reconhecimento(21).

Trazendo o pensamento de Reale ${ }^{(22)}$, a estrutura tridimensional do direito conduz à percepção de que o fenômeno jurídico abarca três aspectos: o normativo, o fático e o axiológico. Quanto ao axiológico, é o valor que confere significado à norma, conformando a conduta humana para atingir determinada finalidade. Assim, se há o reconhecimento de que toda norma jurídica agrega um valor, com muito mais razão as normas de Direitos Humanos, pois versam sobre bens de fundamental importância para seus titulares, aqueles que são usualmente de relevância primordial|(23).

Os Direitos Humanos são definidos por Fernandéz ${ }^{(24)}$ como exigências consideradas imprescindíveis para uma vida digna. A sua natureza moral é destacada por este autor ${ }^{(25)}$ em virtude de essas exigências apresentarem não apenas um caráter jurídico, mas também uma natureza ética ou valorativa.

(18) FREEMAN, M. Human rights. Massachusetts: Polity Press, 2002.

(19) FERNANDÉZ, E. op. cit.

(20) Id. Ibid.

(21) Id. Ibid.

(22) REALE, M. Filosofia do direito. São Paulo: Saraiva, 2003.

(23) NINO, C. S. Ética y derechos humanos. Buenos Aires: Astrea, 2005.

(24) FERNANDÉZ, E. op. cit.

(25) Id. Ibid. 
Sendo assim, os Direitos Humanos são direitos morais porque somam exigências éticas ou valorativas a normas jurídicas. O termo "moral" agregado ao vocábulo "direito", representa a ideia de fundamentação ética e sua estreita relação com a dignidade humana; por sua vez, a palavra "direito" o conduz ao direito positivado. Portanto, "os direitos morais resultam de uma vertente dupla: moral e jurídica"(26). Essa vertente dupla incorpora a matriz jusnaturalista, situando sua fundamentação em parâmetros axiológicos, e a historicista, ao propugnar sua exigência de reconhecimento e proteção, portanto, sua introdução em normas de direito positivo. A fundamentação ética, ao acolher importantes pressupostos das outras duas correntes, busca superar a dicotomia e construir uma noção de Direitos Humanos que se abre para as pertinentes justificações, provenientes de diferentes matrizes.

Os direitos morais, então, são exigências éticas que se moldam no seio da sociedade, independentemente da presença de normas jurídicas positivas, contudo, a existência dessas exigências não é suficiente para permitir o nascimento de um direito moral, pois quando esse não está incorporado ao ordenamento jurídico sua "existência é parcial e incompleta"(27).

Apenas os direitos morais podem ser considerados Direitos Humanos ${ }^{(28)}$. Os valores que se encontram no âmago dos direitos morais existem antes de serem reconhecidos como normas positivadas. Exemplificando, embora uma dada sociedade possa compartilhar o valor da vida humana, consequentemente o dever de não matar, esse valor passa a ser considerado um direito humano quando introduzido numa ordem jurídica. Isso não implica desconsiderar que os Direitos Humanos possam ser percebidos somente sob o viés valorativo, descartando, assim, sua juridicidade.

Os direitos morais são uma moeda com dupla face, uma delas representa a exigência valorativa ou ética, prévia à sua introdução a um ordenamento jurídico, e a outra, a norma jurídica, o que lhe confere efetividade, na medida em que coloca o aparato estatal em benefício daquele cujo direito foi violado. A possibilidade de Ihe atribuir uma natureza ética, prévia ao Estado, permite que possa ser empregado como meio de criticar um ordenamento jurídico que não o reconhece ou o viola e de defender a necessidade de sua incorporação(29). Esse espaço de atuação que é aberto pela aceitação de sua natureza ética não desconsidera que sua existência, sem positivação, é parcial e incompleta.

Os Direitos Humanos devem, enquanto direitos morais, ser entendidos como detentores de dois níveis, um nível axiológico e outro jurídico. No nível axiológico, reconhece-se que os valores éticos são o "substrato e última referência básica dos Direitos Humanos"(30). Contudo, não há uma única

(26) FERNANDÉZ, E. op. cit.

(27) Id. Ibid.

(28) Id. Ibid.

(29) Id. Ibid.

(30) Id. Ibid. 
fundamentação ética que seja válida para todos os Direitos Humanos, com exceção da ideia de dignidade humana. Entretanto, pode-se afirmar que alguns valores e a ideia de dignidade humana respaldam os Direitos Humanos, esses valores seriam basicamente: segurança, liberdade e igualdade ${ }^{(31)}$. Os Direitos Humanos objetivam, em última instância, que a conduta humana seja delineada por esses valores, que não provêm de alguma divindade ou razão superior humana, eles decorrem de condições históricas combinadas com "exigências racionais da consciência moral" humana ${ }^{(32)}$.

Grosso modo, segundo Fernandéz ${ }^{(33)}$, a segurança está atrelada à autonomia e aos direitos pessoais, de segurança individual e jurídica; a liberdade aos direitos civis e políticos; e a igualdade aos direitos econômicos, sociais e culturais. Os direitos baseados na segurança seriam o direito à vida, integridade física, liberdade de consciência e pensamento; os fundados na liberdade seriam os direitos de liberdade de expressão, de reunião e associação, e de participação política; e os alicerçados na igualdade, seriam todos os direitos que ampliam a igualdade formal, os direitos de trabalho, saúde, educação, cultura e seguridade social.

O compromisso com certos valores compreendidos como Direitos Humanos comporta o reconhecimento de que os seres humanos, capazes de participar de práticas e conversações morais, têm certas necessidades básicas e o reconhecimento de que essas necessidades originam fortes obrigações morais ${ }^{(34)}$. Como se nota, Pogge, a despeito de atribuir um poderoso conteúdo moral aos Direitos Humanos, os definindo como "demandas morais que se dirigem à organização da própria sociedade"(35), não os justificam em valores ou exigências éticas, mas sim na ideia de necessidades básicas que ensejam o aparecimento de obrigações morais.

Em síntese, a noção de Direitos Humanos adotada neste trabalho fundamenta-se, como apontado, em dupla perspectiva: jurídica e moral. Assim, os Direitos Humanos são "direitos jurídicos"(36), significando que se encontram previstos em documentos dessa natureza. No entanto, é inconteste que carregam valores cuja existência no meio social é prévia ao seu reconhecimento estatal. Isso possibilita que o respeito aos Direitos Humanos possa ser reclamado frente a sistemas jurídicos que não os reconhecem, mas que se encontram contemplados em instrumentos jurídicos internacionais.

A essência dos Direitos Humanos envolve sua dupla natureza ética e jurídica, isso significa que a sua conformação implica os dois elementos.

(31) FERNANDÉZ, E. op. cit.

(32) Id. Ibid.

(33) Id. Ibid.

(34) POGGE, T. La pobreza en el mundo y los derechos humanos. Barcelona: Paidós, 2005.

(35) Id. Ibid., p. 90.

(36) NINO, C. S. op. cit., p. 15. 
Portanto, a presença de valores socialmente consolidados em uma dada sociedade ou internacionalmente não os conduz necessariamente ao status de Direitos Humanos, porquanto pressupõe seu reconhecimento em algum documento jurídico, quer seja de natureza vinculante ou não.

Concluindo, como afirma Habermas ${ }^{(37)}$ os Direitos Humanos "possuem uma cabeça de Janus voltada ao mesmo tempo para a moral e para o direito". Por um lado, a roupagem de direito jurídico é essencial para sua configuração, e, por outro, relacionam-se como normas morais portando os valores essenciais para a vida social digna. Assim, a substância dos Direitos Humanos compõe-se de duas características, que impõem sua essência: o seu conteúdo moral e a sua formalização em documentos jurídicos.

Compreendida a ideia aceita neste trabalho sobre os contornos dos Direitos Humanos, serão demonstrados no próximo tópico os modos de correlação teórica entre esses e a Bioética.

\section{RELAÇÃO ENTRE BIOÉTICA E DIREITOS HUMANOS: CATEGORIZAÇÃO DAS ABORDAGENS TEÓRICAS}

Não sendo a Bioética simplesmente uma ética, mas sim uma espécie de ética aplicada, não há que se falar em utilizar os critérios gerais de distinção entre a experiência jurídica e a moral para tratar da relação entre Bioética e Direitos Humanos. Da mesma forma, os Direitos Humanos são uma categoria específica de norma jurídica, pois sempre trazem em si aspectos da moralidade conjugados com a normatividade que lhes confere seu reconhecimento em um sistema jurídico positivo. É de aceitação corrente que a maior parte das normas jurídicas está impregnada de cunho valorativo, no entanto, tal relação não é necessária, diferentemente das normas de Direitos Humanos, cuja essência é moral.

Dessa forma, a análise da relação entre Bioética e Direitos Humanos não lança mão dos aportes teóricos comumente utilizados para o exame da relação entre Direito e Moral. A pesquisa da conexão entre Bioética e Direitos Humanos decompõe-se nos seguintes viéses: a influência da Bioética nos Direitos Humanos e a desses últimos na Bioética. É de grande relevância o estudo da influência da Bioética no âmbito dos Direitos Humanos, entretanto, caso esse enfoque fosse o utilizado, esta pesquisa teria seguido o caminho do estudo da Ciência do Direito, com ênfase no fenômeno jurídico. É sabido que a moralidade influencia o Direito de diferentes formas, por exemplo, opiniões morais sobre a interrupção voluntária de gravidez usualmente permeia opções legislativas, assim como decisões judiciais ${ }^{(38)}$. No mesmo

(37) HABERMAS, J. op. cit., p. 148. 
sentido, se coloca a questão de fundo acerca de quando opções morais devem ser convertidas em leis ou no mínimo lhes conferir efeitos legais. Efeitos colaterais do tratamento pelo Poder Legislativo, como da interrupção voluntária de gravidez e eutanásia, são altamente debatidos e complexos ${ }^{(39)}$. Assim, nota-se que a penetração da moralidade no campo jurídico é profícua e a ela devem ser dedicados estudos particulares.

Um dos objetivos centrais deste trabalho é contribuir para a solidificação da Bioética, por isso foi escolhida a abordagem que se centra na influência do mundo legal na esfera da Bioética. As normas jurídicas influenciam as pautas morais em vários aspectos, inclusive conceitos legais estruturam os debates morais ${ }^{(40)}$.

A análise proposta neste estudo da introdução do referencial dos Direitos Humanos na Bioética destaca quatro formas de abordagem dessa interconexão: (i) os Direitos Humanos são inseridos no corpo teórico da proposta bioética; como exemplo tem-se a Bioética de Intervenção desenvolvida por Garrafa e Porto(41); (ii) os Direitos Humanos são trazidos para o campo bioético, enquanto portadores de valores, como a saúde, a integridade física, a privacidade, e integrados ao debate bioético, sem a exclusão das demais abordagens éticas - desenvolvem estudos nessa ótica Andorno ${ }^{(42)}$ e Baker ${ }^{(43)}$; (iii) os Direitos Humanos integram a Bioética compondo uma corrente ética específica denominada "rights-based", cujo fundamento ético seriam os próprios Direitos Humanos - Beauchamp e Childress ${ }^{(44)}$ e Neri(45) expõem teorias éticas a partir dessa proposta; (iv) alguns analisam a interconexão entre Bioética e Direitos Humanos, como Fenton ${ }^{(46)}$, ou elaboram críticas sobre essa relação, como Benatar ${ }^{(47)}$, com o propósito de identificar pontos de contato e distanciamento entre os campos.

Importa salientar que essa abordagem a partir das quatro formas de perceber a interconexão em exame cinge-se à Bioética Teórica, isso significa que a Bioética Normativa e a Institucional não serão analisadas com base nesse recorte. Sendo assim, serão apresentados os contornos das perspectivas teóricas que tratam da interface entre Bioética e Direitos Humanos, nos moldes abaixo.

(38) BURG, W. V. D. Law and bioethics. In: KUSHE, H.; SINGER, P. (Orgs.) A companion to bioethics. New York: Blackwell, 2001. p. 49-57.

(39) Id. Ibid.

(40) Id. Ibid.

(41) GARRAFA, V.; PORTO, D. Intervention bioethics: a proposal for peripheral countries in a context of power and injustice. Bioethics, v. 17, p. 399-416, Oct. 2003.

(42) ANDORNO, R. Global bioethics at UNESCO: in defense of the Universal Declaration on Bioethics and Human Rights. Journal of Medical Ethics, n. 33, p.150-154, 2007.

(43) BAKER, R. Bioethics and human rights: a historical perspective. Cambridge Quaterly of Healthcare Ethics, Cambridge, v. 10, n. 3, p. 241-263, 2001.

(44) BEAUCHAMP, T. L., CHILDRESS J. F. Principles of biomedical ethics. 5. ed. New York: Oxford University Press, 2001. p. 95.

(45) NERI, D. Filosofia moral. São Paulo: Loyola, 2004.

(46) FENTON, E. Genetic enhancement: a threat to human rights? Bioethics, v. 22, n.1, p. 1-7, 2008.

(47) BENATAR, D. Bioethics and Human Rights: a critical view. Journal of medical Ethics, n. 32, v. 1,

p. 17-20, 2006. 


\section{A Bioética de Intervenção}

A Bioética de Intervenção reconhece que a desigualdade entre pobres e ricos e países centrais e periféricos é um dos fatores a ser considerado na análise de situações bioéticas, propondo práticas intervencionistas objetivando contribuir para a criação de condições equânimes entre os indivíduos e Estados ${ }^{(48)}$. A Bioética de Intervenção propugna que a ética deixe de ser percebida apenas sob o prisma privado, ao destacar que seu papel de análise de ações sociais, sanitárias e ambientais é inegável ${ }^{(49)}$. Com isso, a Bioética de Intervenção confere relevância à dimensão pública da ética, destacando sua função na análise de práticas em Saúde Pública, principalmente na determinação de formas de intervenções públicas, na prioridade das ações e formação do pessoal capacitado. Levando em conta a realidade dos países periféricos, a Bioética de Intervenção se ocupa da realização universal dos Direitos Humanos, dentre eles o direito a uma vida digna, representada pela possibilidade de acesso à saúde e outros direitos essenciais para a sobrevivência humana ${ }^{(50)}$.

Dentre os referenciais norteadores da Bioética de Intervenção, são elencados os Direitos Humanos contemporâneos, compreendidos como instrumentos éticos de controle social. São ressaltados os direitos de igualdade e equidade, incorporando um discurso de cidadania ampliada sob o fundamento de que os direitos estão além das garantias advindas dos Estados. A intervenção deve ocorrer para assegurar a todos os seres humanos os direitos de primeira, segunda e terceira geração(51).

Como se nota, o referencial dos Direitos Humanos ocupa amplo espaço na construção teórica da Bioética de Intervenção. São enquadrados como marco norteador, bem como justificantes das ações interventivas. Nesse caso, a introdução dos Direitos Humanos na Bioética se dá por meio da incorporação dos primeiros na proposição teórica dessa vertente enquanto um de seus suportes. A Bioética de Intervenção não realiza a avaliação crítica da interconexão ou a análise das possibilidades e limites da relação entre os dois campos, o foco está no recurso aos valores consubstanciados em normas de Direitos Humanos, tais como igualdade e equidade, bem como na possibilidade de empregá-los como discurso justificante da intervenção.

\section{Direitos Humanos como pauta axiológica para a Bioética}

Esse tipo de abordagem considera os Direitos Humanos de forma mais restrita, os direitos compreendidos no denominado Direito Internacional dos
(48) GARRAFA, V.; PORTO, D. op. cit., p. 87-102.
(49) Id. Ibid.
(50) Id. Ibid.
(51) Id. Ibid. 
Direitos Humanos. Esses direitos são a estrutura essencial e o ponto inicial do desenvolvimento dos princípios bioéticos de estatura internacional(52). Andorno $^{(53)}$ apresenta algumas razões para explicar o apelo aos Direitos Humanos ao se estabelecer normas globais em Bioética. Inicialmente, há uma relação estreita entre as práticas biomédicas e as principais normas de Direitos Humanos, por exemplo, temas como clonagem humana e manipulação do genoma humano concernem intrinsecamente à identidade da espécie humana. Segundo Andorno(54), a razão mais óbvia que justifica a aproximação entre Bioética e Direitos Humanos centra-se no fato de que as atividades biomédicas relacionam-se diretamente com os principais Direitos Humanos básicos, tais como o direito à vida e à integridade física e mental. Dessa aproximação, se infere a possibilidade de se recorrer aos Direitos Humanos para a proteção dos indivíduos de danos no campo biomédico. Ademais, embasar-se nos Direitos Humanos facilita a formulação de padrões universais, pois o Direito Internacional dos Direitos Humanos alicerça-se na assunção que esses direitos básicos transcendem a diversidade cultural. Como no campo bioético a diversidade cultural e ética é o que predomina, sendo, inclusive, o pluralismo uma de suas características, a universalidade dos Direitos Humanos importa para o estabelecimento de pautas éticas compartilhadas, podendo, assim se alcançar mais facilmente princípios bioéticos universais.

Andorno ${ }^{(55)}$ enfatiza o fato dos Direitos Humanos, atualmente, serem uma linguagem comum que propicia o debate e o desenvolvimento de princípios universais em Bioética, bem como registra que a rede composta por normativas e órgãos internacionais constitui um relevante instrumento para proteger a pessoa humana. E esse é um dos principais motivos para integrar o referencial dos Direitos Humanos à Bioética.

Segundo Baker(56) a Bioética e os Direitos Humanos foram concebidos como reação ao horror das atrocidades cometidas durante a Segunda Guerra Mundial. Assim, ambos assentam padrões de suporte para o respeito pelas pessoas; tendem à busca de pautas universais; sustentam alianças de governos e organismos não-governamentais; empregam seus discursos para democratização de elites profissionais; dentre outras características em comum elencadas por Baker(57), que critica a estreiteza da Bioética Estadunidense, pois a impede de alçar espaços internacionais e o desafio de uma Bioética Global. Assevera que para superá-la é preciso voltar-se para o conceito cosmopolita de Direitos Humanos.

(52) ANDORNO, R. Human dignity and human rights as a common ground for a global bioethics. Journal of Medicine and Philosophy, p. 23-28, 2008.

(53) Id. Ibid.

(54) Id. Global bioethics at UNESCO: in defense of the Universal Declaration on Bioethics and Human Rights, cit., p. 150-154.

(55) Id. Ibid.

(56) BAKER, R. op. cit.

(57) Id. Ibid. 
Baker(58) ressalta a ideia de construção de princípios internacionais bioéticos como mecanismos para a proteção dos Direitos Humanos, visto que a linguagem dos direitos já é aceita como o discurso ético internacional. Com efeito, aponta que o discurso baseado nos direitos é o melhor meio disponível para realizar o objetivo compartilhado pela Bioética e pelos Direitos Humanos: a demanda moral de que nunca mais seres humanos sejam tratados sem respeito e com violação à sua dignidade. Uma Bioética internacional baseada no respeito pelos Direitos Humanos é positiva também pelo fato de afastar as disputas entre os diversos princípios bioéticos, que devem, nessa linha de entendimento, proteger os Direitos Humanos.

Pode-se notar que Andorno e Baker estabelecem uma relação profunda entre Bioética e Direitos Humanos, com enfoque no papel que os últimos desempenham no campo bioético. Ambos entendem que os Direitos Humanos, em virtude de traduzirem uma ética comum internacional e com tendência universalista, podem conduzir a consensos em Bioética. Assim, os Direitos Humanos seriam o suporte dos princípios de uma Bioética Global compartilhada. Embora Andorno e Baker façam alusão a outros aspectos que permeiam a interface entre Bioética e Direitos Humanos, conferem peso maior ao universalismo dos Direitos Humanos, essa característica, contestada por muitos teóricos, seria o trunfo que os faz serem tão necessários para o campo bioético. Como ambos tratam da perspectiva de construção de uma Bioética global, é compreensível que os Direitos Humanos tenham ganhado tanto importância na procura de consensos em nível internacional, afinal, é factualmente reconhecido que os Direitos Humanos são normas de cunho moral com aceitação global. E é à luz dessa universalidade que são incorporados à Bioética.

\section{Teorias éticas baseadas em Direitos}

Segundo Néri, a partir da Declaração Universal de Direitos Humanos de 1948 o recurso aos Direitos Humanos passa a fazer parte da "linguagem ética e política contemporânea"(59). Assim, passou-se a conceber os Direitos Humanos como uma forma de ética comum a ser partilhada.

Reúnem-se na intitulada "Ética dos Direitos" aquelas concepções éticas que partem dos Direitos Humanos como vínculos essenciais do agir, enquadrando-se nas éticas deontológicas. Liberalismo Individual: Teoria baseada em Direitos.

Beauchamp e Childress ${ }^{(60)}$ ao fazer referência a teorias éticas situam a teoria baseada em Direitos ao lado do Utilitarismo, da Teoria Kantiana, do

(58) BAKER, R. op. cit.

(59) NERI, D. op. cit. p. 220.

(60) BEAUCHAMP, T. L.; CHILDRESS, J. F. op. cit. 
Comunitarismo e da Ética do Cuidado e reconhecem a importância da linguagem dos Direitos para expressar pontos de vista moral. Importa assinalar que embora Beauchamp e Childress não restrinjam sua abordagem aos Direitos Humanos, percebe-se que é deles que tratam quando expõem uma teoria moral baseada em direitos, pois se referem a direitos previstos nos documentos internacionais como humanos, bem como utilizam a classificação de Direitos Humanos em negativos e positivos. Ademais, a tais direitos fazem menção expressamente ao aludirem aos aspectos favoráveis de uma teoria moral baseada em Direitos.

A Teoria baseada em Direitos evocada por Beauchamp e Childress(61) é analisada como um individualismo liberal, pressupondo a existência de um espaço na sociedade para que os indivíduos desenvolvam seus projetos pessoais. Desde Hobbes o individualismo liberal empregou a linguagem dos direitos para veicular argumentos políticos e morais, assim, historicamente essa linguagem é instrumento para formalizar demandas individuais, notadamente as relacionadas à liberdade.

Não se encontra mais em disputa a legitimidade da tarefa dos direitos civis e políticos de salvaguarda da esfera de liberdade individual das intromissões de outrem ou da coletividade. Contudo, a ideia de que os direitos podem prover a sustentação para teorias morais ou políticas ainda é controversa, como, por exemplo, para muitos utilitaristas e marxistas.

Os autores ${ }^{(62)}$ fazem uma distinção entre direitos legais e direitos morais, os primeiros podem ser justificados em princípios legais, e os segundos se alicerçam em regras e princípios morais. Também classificam os direitos em absolutos e prima facie. Em geral os direitos não são absolutos, com os princípios que prevêem obrigações, são prima facie. Embora a poucos direitos atribuemse o qualificativo absoluto, como o direito a escolher sua própria religião ou a não ter religião, os direitos servem prima facie como barreira para as ações estatais mesmo quando produzam ou maximizem benefícios sociais. Prima facie - presumivelmente válidos - por que em determinadas situações as exigências de utilidade pública podem ter ma significância proeminente que justifique o afastamento ou mitigação de determinados direitos. Daí a diferença entre violar e infringir um direito, violar seria uma ação injustificada contra um direito e infringir refere-se a uma ação justificada que se sobrepõe e um direito.

Há uma correlação entre direitos e obrigações, ou seja, sempre quando um sujeito detém um direito outra parte possui para com ele um dever ou obrigação. Contudo, existem obrigações ou exigências que não apresentam um direito correlato, como as obrigações de caridade. Assim, conclui-se que a linguagem dos direitos é correlativa a da de caráter obrigacional, entretanto, particular contextos devem ser examinados para se afirmar que essa correlação é de mão dupla.

(61) BEAUCHAMP, T. L.; CHILDRESS, J. F. op. cit.

(62) Id. Ibid. 
Alguns filósofos apontados por Beauchamp e Childress ${ }^{(63)}$ incorporam a primazia dos direitos em suas teorias éticas "rights-based" em detrimento das obrigações. Isso se explica em razão da tarefa central da moralidade ser a proteção dos interesses individuais e os direitos consistirem nos instrumentos primários para esse fim, portanto, guias da ação moral são, em verdade, "rights-based".

Ao avaliarem criticamente o Individualismo Liberal, Beauchamp e Childress ${ }^{(64)}$ expõem quatro críticas: i. o problema de se centrar a ética em uma teoria baseada em Direitos é a parca abrangência da linguagem jurídicas, pois abarcam apenas uma parte do fenômeno moral, cuja complexidade e penetração social é maior; ii. há questões normativas sobre o exercício dos direitos, ou seja, às vezes o que se coloca moralmente não é se alguém possui determinado direito mas até que ponto ele deve ser exercido ou como deve. Assim, mesmo que se tenha uma completa teoria dos Direitos, questões relacionadas a obrigação moral ou não de exercê-los perdura; iii. o Individualismo Liberal confere ênfase exacerbado ao indivíduo negligenciando a importância da coletividade e de bens comuns, como, por exemplo, a Saúde Pública; iv. a "rights-based" teoria que muitas vezes percebe dilemas morais criando conflitos entre os direitos das partes envolvidas, dificultando, assim, sua solução e até mesmo criando contraposições ou insuflando-as.

Quanto a uma percepção construtiva do Individualismo Liberal, os autores $^{(65)}$ aceitam os Direitos Humanos básicos, positivos e negativos, como meios de atendimento de propósitos morais e sociais. Ressaltam, ademais, que não há linguagem mais adequada para a proteção do indivíduo em nível político, reconhecendo que injustiças e tratamentos desumanos ocorrem com maior frequência em países que falham em adotar os Direitos Humanos em seus documentos ou seu discurso.

Também não deixam de lado o fato de que os Direitos Humanos ultrapassam fronteiras e se revelam como os parâmetros internacionais para o tratamento das pessoas. E que a sustentação da dignidade e do autorespeito em direitos exigíveis conferem maior autonomia à pessoa humana $\mathrm{e}$ possibilidade de defesa de seus projetos pessoais, pois, a linguagem obrigacional centra o dever de tratar outrem dignamente na vontade do obrigado, deixando o agente em posição vulnerável.

\section{Perspectiva descritiva da interface}

Alguns teóricos não têm a intenção de destacar um ponto de contato entre a Bioética e os Direitos Humanos ou de aprofundar ou utilizar o

(63) BEAUCHAMP, T. L.; CHILDRESS, J. F. op. cit.

(64) Id. Ibid.

(65) Id. Ibid. 
referencial dos Direitos Humanos como alicerce de sua estruturação teórica Bioética. Com efeito, os agora tratados, Fenton e Benatar, desenvolvem uma análise das conexões entre a Bioética e os Direitos Humanos.

Fenton ${ }^{(66)}$, ao sistematizar pontos de aproximação, enumera quatro razões para alicerçar a interface entre Bioética e Direitos Humanos: a primeira refere-se a problemáticas planetárias que afetam diversas regiões do globo, sem limites fronteiriços, e demandam soluções de caráter intercultural, sem espaço territorial previamente delimitado. A caracterização de determinados dilemas bioéticos como planetários conduz à reflexão de que apenas uma Bioética Global estaria apta a lidar com questões de tamanha abrangência. A linguagem dos Direitos Humanos alinhavaria as diversas concepções bioéticas, já que constitui uma pauta ética universal que transcende religiões, fronteiras físicas e culturas, com potencial para florescer ao redor do globo.

A segunda razão relaciona-se com a relevância atribuída por alguns bioeticistas à linguagem dos Direitos Humanos na esfera da Saúde Pública. Sabe-se que variados dilemas bioéticos surgem no desenrolar das ações de Saúde Pública e que, a despeito da Bioética ter se consolidado academicamente como uma ética biomédica, atualmente clama-se pela sua inserção em outros espaços, como a Saúde Pública. Ao se introduzir a reflexão bioética nessa frente, o instrumental teórico e prático mais adequado é fornecido pelos Direitos Humanos, devido à sua universalidade e ênfase na igualdade e dignidade ${ }^{(67)}$. A Saúde Pública vincula-se diretamente com o direito humano à saúde, e, logo, encontra-se imbricada com seus dois desdobramentos: o direito a assistência sanitária - no que concerne aos serviços de saúde e os Direitos Humanos relacionados aos determinantes em saúde - relativos aos diversos fatores sócio-econômicos que interagem com o bem-estar físico, mental e social da pessoa humana.

A terceira justificante para a interface analisada refere-se aos valores compartilhados entre a Bioética e os Direitos Humanos. A existência de valores compartilhados entre Bioética e Direitos Humanos faz com que se toquem e troquem construtos teóricos e práticos advindos de cada campo. A Bioética, enquanto reflexão sobre as "questões de ética suscitadas pela medicina, pelas ciências da vida e pelas tecnologias que lhes estão associadas" visa proteger um rol de valores fundamentais para a dignidade da pessoa humana, tais como a vida, a saúde, a integridade física e mental e a liberdade; na mesma direção, os Direitos Humanos são instrumentos jurídicos, cujo princípio matricial é a dignidade humana e trazem em si, preenchendo-lhes materialmente, valores caros para a humanidade. A Bioética encontra-se conectada com os Direitos Humanos por meio de valores universais que se encontram acolhidos no direito internacional dos Direitos Humanos.

(66) FENTON, E. op. cit.

(67) ANNAS, G. American bioethics: Crossing human rights and health law boundaries. New York: Oxford, 2005. 
A quarta e última razão apontada baseia-se na existência de um sistema de proteção internacional dos Direitos Humanos e na possibilidade de sua utilização com o escopo de proteger a dignidade da pessoa humana, bem como de outros valores relacionados a questões éticas suscitadas pela medicina, ciências da vida e tecnologias correlacionadas. Fenton ${ }^{(68)}$ aponta que os Direitos Humanos, por constituírem um corpo de normativas positivadas, revelam uma coercitividade ausente nas normas somente de natureza ética. A despeito do sistema internacional de proteção dos Direitos Humanos se depararem com diversas dificuldades práticas para sua operacionalização e implementação, não há como negar que sua existência há décadas, materializada em instrumentos jurídicos vinculantes e órgãos especializados, significam um grande avanço para a proteção da dignidade humana e valores correlatos. Nesse sentido, a Bioética, ao dividir um espaço de intersecção com os Direitos Humanos no que toca a tais valores, também se beneficia da aproximação com os Direitos Humanos e consequente utilização do seu sistema de proteção.

Por outro lado, Benatar ${ }^{(69)}$ desenvolve uma série de argumentações com o objetivo de demonstrar a fraqueza da interface entre Bioética e Direitos Humanos a partir das diferenciações entre os dois campos. O primeiro ponto de distinção está no fato do direito sempre contar com um dever correlato, a inscrição legal de um direito implica o dever da outra parte de cumpri-lo. 0 segundo aspecto distintivo se encontra na coercitividade que usualmente acompanha o direito, a esse acresce a impossibilidade dos direitos abarcarem uma gama ampla de conceitos morais, assim como darem conta da complexidade do fenômeno moral.

Benatar ${ }^{(70)}$ destaca o fato de que no campo moral existem deveres que não encontram correspondência em direitos, como, por exemplo, o dever de ser caridoso. Em consequência, uma ética baseada apenas em direitos, tal como a proposta pela corrente que reúne saúde e Direitos Humanos, ignora que deveres não são correlativos a direitos. No mesmo sentido, tal ética não contempla a noção de "bem" ou a de virtudes, pois não podem ser discutidos amplamente na linguagem dos direitos. Assim, conclui que a moralidade é uma temática complexa e essa complexidade não pode ser manejada somente com o emprego dos direitos.

Ao criticar pontualmente o recurso aos Direitos Humanos, Benatar ${ }^{(71)}$ registra que o conceito de Direitos Humanos não abrange os demais direitos que não são assim classificados, como os direitos relacionados à relação que se estabelece entre o consumidor e uma operadora de planos privados de saúde. A mesma restrição se apresenta quanto aos animais envolvidos em

(68) FENTON, E. op. cit.

(69) BENATAR, D. op. cit.

(70) Id. Ibid.

(71) Id. Ibid. 
experimentações, pois os Direitos Humanos não os protegem. Para enfatizar a incapacidade dos Direitos Humanos de abarcar a complexidade do fenômeno moral, afirma que lançar mão dos Direitos Humanos em qualquer situação é semelhante a prescrever o mesmo medicamento para todas as doenças.

Por outro lado, reconhece que os direitos fazem parte da ética, porém, ressalva que não se confunde com sua inteireza, sendo assim, a abordagem baseada nos Direitos Humanos quando aplicada à saúde não substitui a reflexão Bioética, como um todo.

Tanto Benatar quanto Fenton não têm como dada a interconexão entre Bioética e Direitos Humanos. Fenton tem como intuito construir as bases dessa conexão demonstrando as razões que apóiam a conjugação dos dois campos. A tarefa de Benatar é mais complexa, ele analisa a relação entre Bioética, direito em geral, Direitos Humanos, e o referencial específico denominado Saúde e Direitos Humanos com o fito de expor os motivos pelos quais entende que muitas vezes alguns teóricos superestimam o papel dos Direitos Humanos na esfera da saúde, assim como na análise ética.

Como visto, não há um consenso entre os bioeticistas acerca de como analisar a interface entre Bioética e Direitos Humanos ou de que forma esses podem ser incorporados à reflexão bioética, sob a perspectiva teórica. No próximo tópico, também num viés teórico, serão expostos os pontos de aproximação e separação entre os Direitos Humanos e a Bioética, com ênfase na relação entre Bioética e Direitos Humanos no âmbito da Saúde Pública.

\section{PONTOS DE CONTATO E DISTANCIAMENTO}

O termo "bioética" foi empregado pela primeira vez na década de setenta por Potter, cuja preocupação central era o desenvolvimento tecnológico e suas consequências ambientais para o planeta. Para Potter ${ }^{(72)}$, as ciências deveriam estar acompanhadas de uma reflexão ética para que as intervenções na natureza não se dessem de forma inconsequente. Assim, apesar do vocábulo "bioética" ter surgido como uma proposta de junção das ciências exatas e biomédicas com as humanas, alguns autores ${ }^{(73)}$ sustentam a ideia de que a percepção de que essas ciências podiam, sem uma reflexão ética, ser aplicadas de forma a causar males para os seres humanos e o planeta advém de um período histórico anterior. Segundo Annas ${ }^{(74)}$, as atrocidades praticadas pelos médicos nazistas nos campos de concentração, por meio da utilização de prisioneiros como sujeitos de pesquisa, revelam que a prática da medicina e a ideia da inexorabilidade do desenvolvimento científico

(72) POTTER, V. R. Bioethics: a bridge to the future. Englewood Cliff: Prentice-Hall, 1971.

(73) ANNAS, G. op. cit. ANDORNO, R. Global bioethics at UNESCO: in defense of the Universal Declaration on Bioethics and Human Rights, cit.

(74) ANNAS, G. op. cit. 
podem, em certas circunstâncias, levar à violação de direitos básicos, como a integridade física e psíquica. Com o término da Segunda Guerra Mundial e a constituição do Tribunal de Nuremberg para o julgamento dos médicos nazistas, os juízes verificaram que havia uma lacuna normativa, ou seja, não havia normas que regulamentassem a experimentação envolvendo seres humanos. Diante desse fato, os juízes elaboraram um conjunto de dez princípios norteadores da pesquisa envolvendo seres humanos, com ênfase no consentimento informado, que foram denominados de Código de Nuremberg. $\mathrm{O}$ Código de Nuremberg, de 1949, é um documento internacional que registra a necessidade de que a exploração científica respeite os direitos dos seres humanos que estejam nela envolvidos. Por isso é historicamente considerado um fato essencialmente bioético mesmo antes do seu surgimento enquanto disciplina acadêmica.

Os Direitos Humanos têm seu marco de reconhecimento formal na Declaração de Independência Americana de 1776 e na Declaração dos Direitos do Homem e do Cidadão de 1789, que reconheceram os direitos civis e políticos. Os direitos sociais, econômicos e culturais, frutos dos movimentos socialistas do final do século XIX, apresentam como marco normativo as Constituições do México de 1917 e a da Alemanha de 1919, nas quais se tem a previsão de direitos trabalhistas e do direito à educação. A internacionalização dos Direitos Humanos com o alargamento de seu alcance para um nível global deu-se com o final da Segunda Guerra Mundial. O Tribunal de Nuremberg que julgou criminosos de guerra nazistas inovou a ordem jurídica internacional com a criação dos chamados crimes contra a humanidade, ou seja, a partir daquele momento alguns crimes não atingiam apenas uma pessoa ou determinada coletividade, mas sim toda a humanidade. Em razão de determinadas características, os agentes desses crimes tinham que ser punidos mesmo que o Estado ao qual se encontravam subordinados não o fizesse. Houve o reconhecimento, decorrente dessa nova percepção, de que a pessoa humana precisava ser protegida por um órgão supra-estatal e que existiam direitos que, mesmo não sendo reconhecidos pelos Estados, deviam ser assegurados. A Declaração Universal de Direitos Humanos, de 1948, cujo preâmbulo faz alusão às atrocidades cometidas durante a Segunda Guerra, reconhece direitos civis, políticos, sociais, econômicos e culturais para todas as pessoas humanas e o dever dos Estados de respeitá-los, protegê-los e realizá-los.

A Bioética e os Direitos Humanos aproximam-se historicamente. A internacionalização dos Direitos Humanos, resposta à capacidade de destruição e banalização da vida humana vistas durante a Segunda Guerra, e a percepção de que as práticas científicas podiam violar valores humanos básicos, como o respeito à pessoa humana, que deu ensejo ao julgamento dos médicos nazistas, fundamentaram-se, direta e indiretamente, na ideia de dignidade humana. A acepção nazista de "vida sem valor vital" que gerava a ideia de que existiam pessoas de "segunda classe", as quais, portanto, não 
eram merecedoras do mesmo respeito, afetou diretamente a humanidade ${ }^{(75)}$. O preâmbulo da Declaração Universal faz referência à dignidade inerente de todas as pessoas e o Código de Nuremberg determina que todo experimento deva ser conduzido de maneira a evitar todo sofrimento e danos desnecessários, quer físicos, quer materiais, o que demonstra preocupação com a pessoa humana.

Nota-se que a Bioética e os Direitos Humanos surgem como aportes que objetivam assegurar determinados valores e proteger a pessoa humana, reconhecendo sua dignidade inerente. Assim, a Bioética e os Direitos Humanos apresentam dois pontos de aproximação: a dignidade humana e determinados valores básicos. O princípio da dignidade humana, reconhecido na Declaração Universal dos Direitos Humanos, no Pacto Internacional sobre os Direitos Civis e Políticos, e no Pacto Internacional sobre os Direitos Sociais, Econômicos e Culturais, de 1966, é, no campo dos Direitos Humanos, entendido como a rocha sobre a qual a superestrutura dos Direitos Humanos se constrói, porque é dele que emana o fundamento para todos os Direitos Humanos. Para a Bioética, o princípio da dignidade humana é marco axiológico da Bioética Global, tendo sido acolhido pela Convenção de Oviedo, Declaração Universal de Bioética e do Genoma Humano, e da Declaração Universal sobre Bioética e Direitos Humanos. A dignidade humana, como apontado por Lenoir, Mathieu ${ }^{(76)}$ e outros, é o mais evidente ponto de aproximação entre a Bioética e os Direitos Humanos, sendo o princípio fundamental e alicerce de toda construção teórica nos dois campos do saber. Além do princípio da dignidade humana, a Bioética e os Direitos Humanos apresentam outro ponto de aproximação, que são valores partilhados, como os consensualmente adotados na Declaração Universal sobre Bioética e Direitos Humanos, de 2005. A Bioética em sua perspectiva prescritiva propõe soluções para dilemas morais e os Direitos Humanos, normas de natureza ética e jurídica, estabelecem comandos dirigidos aos Estados. Ambos, então, propõem normas para pautar a atuação de atores sociais com base em valores humanos histórica e socialmente construídos. Os Direitos Humanos, formalizados em normas internacionais, condensam valores que foram consensualmente acordados como essenciais para o convívio social; e a Bioética, ao propor formas de resolução de conflitos morais, fundamenta-se também em valores humanos surgidos em determinado contexto social e histórico.

Partindo-se de que a Bioética e os Direitos Humanos possuem a dignidade humana e determinados valores como pontos de aproximação, é importante para a presente pesquisa destacar as especificidades de cada área. A Bioética é entendida de forma predominante como ética aplicada,

(75) ANDORNO, R. Bioética y dignidad de la persona. Madrid: Tecnos, 1998. p. 35.

(76) LENOIR, N.; MATHIEU, B. Les normes internationales de la bioéthique. Paris: PUF, 2004. 
embora haja inúmeras divergências quanto à sua natureza e em razão delas o termo "bioética" não foi o adotado na Convenção de Oviedo. No entanto, entendendo a Bioética como ética aplicada, observa-se que o conteúdo das suas prescrições é de natureza moral sem força coercitiva, ao passo que os Direitos Humanos apresentam uma relativa coercitividade, com a previsão de formas de monitoramento da sua efetivação por alguns documentos internacionais.

Um dos fatores históricos que marcou o surgimento da Bioética foi a emergência de moralidades plurais, como os movimentos de direitos civis na década de sessenta nos Estados Unidos. A partir desse período, o mundo ocidental, anteriormente fechado numa cosmovisão única, presenciou a fala de minorias e o rompimento com um padrão monolítico de moralidade. Esse pluralismo moral permitiu o surgimento da Bioética e permanece como sendo uma das suas principais características, o que justifica a existência de correntes laicas e religiosas convivendo harmonicamente.

Diferentemente, os Direitos Humanos tendem para o universalismo das suas normas, tendo sido essa característica reconhecida pelos 184 países participantes da Segunda Conferência Mundial dos Direitos Humanos, realizada em Viena, no ano de 1993. Assim, constata-se que desde a Declaração e Programa de Ação de Viena, os Direitos Humanos são aceitos como universais e indivisíveis. Essa tensão entre o pluralismo moral ínsito à Bioética e o universalismo essencial para os Direitos Humanos traz consequências importantes a serem estudadas para os dois campos.

Outro aspecto relevante que diferencia as duas áreas relaciona-se com os atores sociais envolvidos na concretização de suas prescrições. A Bioética ao apresentar resoluções para dilemas morais a partir da avaliação ética o faz por meio de coletivos agrupados para essa função. Exemplificando, existem as comissões nacionais de bioética, que são órgãos de composição plural que analisam e propõem soluções para problemáticas bioéticas abstratas, normalmente de interesse para toda sociedade; comitês de pesquisa, que analisam a adequação ética de protocolos de pesquisa que envolva seres humanos; e comitês de ética hospitalar, que são instâncias dentro de hospitais compostas por profissionais de saúde e de outras áreas que analisam e deliberam sobre questões concretas que envolvem dilemas morais. Como se vê, os atores sociais que prescrevem ações em Bioética não são necessariamente vinculados ao Estado, nem suas normas apontam para uma relação entre indivíduo e Estado.

Os Direitos Humanos são normas, cujos sujeitos - passivo e ativo são o indivíduo e o Estado, e derivam de organismo supra-estatal composto por Estados ou do próprio Estado, porquanto sempre há a participação estatal na formação das normas internacionais e nacionais de Direitos Humanos. Quanto à titularidade dos Direitos Humanos, tradicionalmente atribui-se a pessoas humanas detentoras dos direitos civis, políticos, sociais, econômicos 
e culturais, uma vez que a titularidade coletiva é uma questão controvertida no seu âmbito. A Bioética, por meio das duas Declarações da UNESCO sobre genética humana, a Declaração Universal sobre Bioética e Direitos Humanos, traz a necessidade de proteção do genoma humano e da biodiversidade, cujos titulares são a humanidade, e também traz a titularidade de direitos das futuras gerações, apontada na Declaração Universal das Futuras Gerações da UNESCO. Para a Bioética, revela-se essencial trabalhar com a ideia de respeito dirigido a sujeitos difusos, o que se mostra um desafio para o campo dos Direitos Humanos, pois esses ainda estão atrelados à ideia de que apenas os Estados e a pessoa humana são sujeitos de direito internacional.

Considerando os pontos de aproximação e distanciamento, esta pesquisa parte do pressuposto de que existe uma interface entre Bioética e Direitos Humanos. Essa interface fundamenta-se no fato de que ambas as áreas apresentam como núcleo principiológico a dignidade humana e têm como propósito a proteção e a defesa de valores em comum.

Assim, entende-se que existe um espaço de intersecção entre Bioética e Direitos Humanos, isso significa que a relação entre ambos pode ser graficamente representada por meio de dois círculos que se interpenetram, fazendo existir uma área comum. Isto é, a Bioética se desenvolve em diversas searas sem a interconexão com os Direitos Humanos e, da mesma forma, os Direitos Humanos atuam em diversos campos que não têm qualquer relação com temáticas bioéticas, porém, existe um espaço compartilhado entre as duas disciplinas que incorporam elementos advindos de ambas. Essa extensão que atravessa os dois campos não está claramente configurada. Essa configuração imprecisa se dá primeiramente pelo fato de que a Bioética, disciplina recente, apresenta complexas controvérsias quanto ao seu conteúdo, e disso decorre a negação por alguns da existência de conexão com os Direitos Humanos. Em segundo lugar, a despeito de alguns teóricos desenvolverem essa correlação em alguns artigos, constata-se que ainda não se encontra academicamente amadurecida para que se possa aplicá-la a situações concretas. E, por fim, os teóricos dos Direitos Humanos, na sua grande maioria juristas, não se dedicam ao estudo da Bioética de forma aprofundada, centrando-se em temáticas bioéticas específicas e não no seu entendimento epistemológico.

Portanto, o estudo dessa interface é relevante para que dois saberes que apresentam claramente a dignidade da pessoa humana como princípiodiretriz possam compartilhar instrumentos teóricos e práticos, com o escopo de que sejam empregados por aqueles que detêm força decisória nas mais diversas instâncias. Com efeito, a Bioética e os Direitos Humanos não se constituem apenas como campos teóricos, formulam prescrições de alcance até mesmo universal. Assim, as pesquisas que comprovem a existência de valores compartilhados pelas duas disciplinas reforçam a ideia de que suas 
prescrições devem ter como conteúdo tais valores, identificados como essenciais para o convívio humano harmonioso.

No mesmo sentido, a análise das implicações envolvendo os Direitos Humanos no campo da Saúde Pública consiste numa proposta de construção de uma reflexão em Bioética fundamental para que bioeticistas não apenas pensem sobre dilemas morais nessa esfera, mas também possam formular normas com maior capacidade interventiva. Em virtude dessa acepção, nos parágrafos seguintes serão expostos brevemente os meandros que permeiam a relação entre Bioética, Direitos Humanos e Saúde Pública.

Estudar a interface entre Direitos Humanos e Bioética consiste na abertura de um novo espectro de reflexão dentro dessa, pois, a despeito dessa correlação essencial, há um pequeno número de estudos que têm como objetivo específico essa aproximação. Da mesma forma, aproximar Saúde Pública e Direitos Humanos contribui para que o arcabouço teórico em torno da avaliação ética de práticas em Saúde Pública seja reforçado, bem como para que sejam construídos aportes hábeis para se analisar a ação estatal nesse campo.

Por outro lado, é indispensável traçar uma linha divisória entre problemáticas bioéticas que se enquadram no referencial dos Direitos Humanos e as que, por questões que não serão objeto desta pesquisa, não têm pertinência com os referidos Direitos, para que se possa objetivar a aplicação do aludido referencial em questões morais concretas. Desse modo, considerando que nem todos os dilemas em Bioética são passíveis de serem analisados sob a ótica dos Direitos Humanos, constata-se a necessidade de sistematização de formas de aproximação entre Bioética e esses direitos, objetivando aplicá-los concretamente a problemas morais. Então, dentre os temas que se enquadram nessa perspectiva pode-se destacar a Saúde Pública, pois em razão da sua universalidade e da sua ênfase na igualdade e dignidade, a linguagem dos Direitos Humanos é a mais bem adequada ${ }^{(77)}$. A aplicação do princípio da dignidade humana na Saúde Pública é essencial para se contrabalançar o predomínio da ética utilitarista usualmente adotada como fundamentação de programas e ações de saúde. Pois, o utilitarismo pode ser caracterizado como a "tirania da maioria"(78), haja vista que a busca da maior quantidade de felicidade para o maior número de pessoas muitas vezes acarreta a violação de interesses e valores individuais. Ainda, a perspectiva dos Direitos Humanos é fundamental para a incorporação à Saúde Pública dos determinantes sociais da saúde, como educação, alimentação, condições sanitárias, na medida em que, segundo a doutrina dos Direitos Humanos, a realização do direito à saúde se imbrica com a dos demais Direitos Humanos, o que se denomina a interdependência de tais Direitos.

(77) ANNAS, G. op. cit.

(78) THOMAS, J. C. Public health ethics. In: SCUTHFIELD, F.D.; KECK, C.W. (Orgs.). Principles of public health practice. New York: Delmar, 2009. p. 133-148. 
A Saúde Pública implica vinculação entre indivíduo e Estado, relação essa que essencialmente se traduz na ligação presente nos Direitos Humanos - direito individual e dever estatal; bem como a Saúde Pública está atrelada ao desenvolvimento de políticas públicas, o que está imbricado com o dever do Estado de respeito aos Direitos Humanos.

A propósito, cabe salientar que a função da Saúde Pública é assegurar as condições de vida saudável, nas quais se incluem uma variedade de fatores: econômicos, sociais, ambientais que guardam relação direta com o estado de saúde individual e coletivo(79). Assim, a Saúde Pública tem como escopo central proteger a saúde da população e torná-la melhor mediante a adoção de meios coletivos, principalmente pelo Estado.

Atualmente, verifica-se a existência de uma série de estudos específicos destinados a pesquisar teórica e praticamente a aplicação do referencial dos Direitos Humanos à Saúde Pública. Por outro lado, há investigações cujo objeto é a ética na Saúde Pública. Na esfera bioética, também se observa a atenção de alguns bioeticistas para com questões morais de Saúde Pública.

Desse breve quadro acima, infere-se que a inserção dos Direitos Humanos, enquanto referencial bioético, na análise de dilemas morais de Saúde Pública perpassa o exame das três vertentes apontadas: Saúde e Direitos Humanos; Saúde Pública e Ética; Bioética e Saúde Pública. Tendo em conta as limitações físicas deste artigo, não se fará tal investigação, somente, lança-se a ideia, que vem sendo desenvolvida em trabalho doutoral, de que a automática incorporação dos Direitos Humanos, qualquer que seja o direito (mesmo o direito humano à saúde) ao discurso bioético não é aceitável, pois normas de Direitos Humanos possuem um conteúdo jurídico incontestável, apartando-se, destarte, da natureza de ética aplicada da Bioética. Entretanto, viu-se neste trabalho que os Direitos Humanos também detêm um conteúdo ético ou moral, o qual se condensa nos princípios de Direitos Humanos, posto que o conteúdo axiológico dos princípios é indiscutível. No caso da Saúde Pública, são aplicados os seguintes princípios dos Direitos Humanos: princípios da não-discriminação, igualdade e da participação social, responsabilidade, e proteção dos vulneráveis.

A questão que se coloca é: como incorporar os Direitos Humanos às análises bioéticas de problemáticas de Saúde Pública sem descaracterizar a Bioética e torná-la mais um campo jurídico. A resposta para tal controvérsia implica o exame das três vertentes aludidas, o que impõe extensa análise dos referenciais teóricos envolvidos, fugindo da proposta deste trabalho. No entanto, vislumbra-se que o recurso aos princípios de Direitos Humanos aplicáveis à Saúde Pública pode ser uma pista para o desenlace da temática

(79) GOSTIN, L. O. Teorias de la justicia y responsabilidad social en la salud pública. In: MALAGA, Hernán (Org.). Salud pública: enfoque bioético. Caracas: Disinlimed, 2005. 
ora posta, pois se tratando do modelo de princípios não se afasta da linguagem predominante atualmente da Bioética, que é a principiológica.

\section{CONSIDERAÇÕES FINAIS}

Neste trabalho focou-se estritamente o exame da interface entre Bioética e Direitos Humanos à luz dos aportes teóricos dedicados à primeira. $\mathrm{O}$ exame da literatura bioética atual demonstrou que a relação entre os dois campos pode ser resumida da seguinte forma: a) existência de construções bioéticas que consideram os Direitos Humanos como parâmetro e pauta axiológica para a Bioética, notadamente a Bioética Global, como exemplo tem-se a Declaração Universal sobre Bioética e Direitos Humanos; b) ações de bioeticistas que incorporam os Direitos Humanos a seus construtos teóricos, levando-os à condição de marco referencial de análise de dilemas bioéticos, c) propostas teóricas que não consideram os Direitos Humanos e seus princípios não são vistos como normas condensadoras de valores, o enfoque recai sobre as formas de conexão e afastamento da Bioética, sem ocupar-se de sua aplicação a dilemas morais em Bioética.

Assim, nota-se que na Bioética, atual e ocidental, a interface objeto deste estudo pode ser assim sintetizada: há um amplo reconhecimento de que os princípios, valores e normas de Direitos Humanos são referenciais para a reflexão e prescrição de dilemas bioéticos, no entanto, para algumas correntes bioéticas e determinados teóricos é perfeitamente possível e desejável a análise bioética sem o emprego do marco dos Direitos Humanos. Em suma, em termos teóricos, não se constata a presença de discurso uníssono sobre a conexão entre a Bioética e os Direitos Humanos, o que enuncia o processo de construção que ainda se encontra a Bioética, assim como a pluralidade de fundamentações éticas que permeia sua produção teórica.

Também se verificou que a Bioética e os Direitos Humanos são dois campos do saber que compartilham valores éticos, assim, constata-se que a despeito da variedade de correntes Bioéticas, a maior parte delas se entrelaça com a pauta axiológica justificante das normas de Direitos Humanos, tais como: justiça, igualdade, autonomia e liberdade. Contudo, o reconhecimento da relevância dos Direitos Humanos para a proteção e concreção de valores bioéticos não legitima a subsunção da Bioética aos Direitos Humanos, ou seja, os Direitos Humanos não se constituem num referencial ético exclusivo para a descrição e prescrição de dilemas bioéticos. No entanto, quando se trata de dilemas morais em Saúde Pública, buscou-se demonstrar que a análise Bioética, uma vez escolhido este parâmetro ético avaliativo, pode lançar mão de princípios de Direitos Humanos. O que é aconselhável, mormente em razão de tais princípios constituírem embasamento ético da atuação do Estado, o principal responsável pela proteção da saúde da população. 
Com efeito, uma Bioética sustentada teoricamente na utilização do referencial dos Direitos Humanos consiste num saber que possibilita a tomada de decisões melhor fundamentadas por parte dos responsáveis por políticas de saúde. Desta forma, haverá uma aproximação entre a Bioética e os problemas em Saúde Pública, com a otimização da relação entre meios e fins das políticas públicas sanitárias, visto que por meio de uma análise bioética com emprego dos Direitos Humanos pode-se avaliar com mais precisão suas consequências para a população. Portanto, a eficácia e a efetividade de políticas em Saúde Pública podem ser aferidas mediante o emprego de uma Bioética conjugada com os Direitos Humanos.

\section{REFERÊNCIAS BIBLIOGRÁFICAS}

ANDORNO, R. Bioética y dignidad de la persona. Madrid: Tecnos, 1998.

. Global bioethics at UNESCO: in defense of the Universal Declaration on Bioethics and Human Rights. Journal of Medical Ethics, 33, p.150-154, 2007.

Human dignity and human rights as a common ground for a global bioethics. Journal of Medicine and Philosophy, p. 23-28, 2008.

Towards in international bioethics law. Journal International de Bioéthique, n. 23, v.15, Jan./sept. 2004.

ANNAS, G. American bioethics: Crossing human rights and health law boundaries. New York: Oxford, 2005.

BAKER, R. Bioethics and human rights: a historical perspective. Cambridge Quaterly of Healthcare Ethics, Cambridge, v. 10, n. 3, p. 241-263, 2001.

BARRETO, V. Bioética, biodireito e direitos humanos. In: TORRES, R. Lobo (Org.) Teoria dos direitos fundamentais, Rio de Janeiro: Renovar, 1999. p. 377-417.

BEAUCHAMP, T.L.B. Introduction to ethics. In: BEAUCHAMP, T.L.; WALTERS, L. (Orgs.) Contemporary issues in bioethics. New York: Thomson, 2003. p. 1-37.

BEAUCHAMP, T. L., CHILDRESS J. F. Principles of biomedical ethics. 5. ed. New York: Oxford University Press, 2001.

BENATAR, D. Bioethics and Human Rights: a critical view. Journal of Medical Ethics, n. 32, v. 1, 2006, p.17-20.

BOBBIO, N. A era dos direitos. São Paulo: Campus, 1993.

BUENO, G. Que es la bioética. Oviedo: Pentalfa, 2001.

BURG, W. V. D. Law and bioethics. In: KUSHE, H.; SINGER, P. (Orgs.) $A$ companion to bioethics. New York: Blackwell, 2001. p. 49-57. 
CALLAHAN, D. Bioethics. In: ENCYCLOPEDIA of bioethics. 3. ed. New York: Macmillan, 2004. p. 278-287.

DURAND, G. Introdução geral à bioética.São Paulo: Loyola, 2003.

FENTON, E. Genetic enhancement: a threat to human rights? Bioethics, v. 22, n.1, p. 1-7, 2008.

FERNANDÉZ, E. Teoria de la justicia y los derechos humanos. Madrid: Editorial Debate, 1984.

FREEMAN, M. Human rights. Massachusetts: Polity Press, 2002.

GARRAFA, V. Intervention bioethics epistemology for peripheral countries. Journal International de Bioétique, v.19, n. 1-2, p.87-102, 2008. Bioethics in Brazil (special issues)

GARRAFA, V.; PORTO, D. Intervention bioethics: a proposal for peripheral countries in a context of power and injustice. Bioethics, v. 17, p. 399-416, Oct. 2003.

GOSTIN, L. O. Teorias de la justicia y responsabilidad social en la salud pública. In: MALAGA, Hernán (Org.). Salud pública: enfoque bioético. Caracas: Disinlimed, 2005.

HABERMAS, J. A constelação pós-nacional. São Paulo: Littera Mundi, 2001. INSTITUTO DE BIOÉTICA. Direitos do homem e biomedicina. Lisboa: Universidade Católica, 2003.

KOTTOW, M. Introducción a la bioética. Santiago do Chile: Mediterráneo, 1995.

LENOIR, N.; MATHIEU, B. Les normes internationales de la bioéthique. Paris: PUF, 2004.

NERI, D. Filosofia moral. São Paulo: Loyola, 2004.

NINO, C. S. Ética y derechos humanos. Buenos Aires: Astrea, 2005.

PARIZEAU, M. H. Bioética. In: CANTO-SPERBER, M. (Org.). Dicionário de ética e filosofia moral. Caxias do Sul: Unisinos, 2003.

POGGE, T. La pobreza en el mundo y los derechos humanos. Barcelona: Paidós, 2005.

POTTER, V. R. Bioethics: a bridge to the future. Englewood Cliff: PrenticeHall, 1971.

REALE, M. Filosofia do direito. São Paulo:Saraiva, 2003.

THOMAS, J. C. Public health ethics. In: SCUTHFIELD, F.D.; KECK, C.W. (Orgs.). Principles of public health practice. New York: Delmar, 2009. p. 133-148. 